\title{
Striving for a Coming Community and the Question of a Life
}

\author{
Hélène Frichot
}

\section{Introduction}

The concepts of the coming community, which we discover in Giorgio Agamben's work, and of a future people, treated by Gilles Deleuze and Félix Guattari in What is Philosophy?, appear to be utopian formulations of community. They seem to forestall, indefinitely, the arrival or satisfaction of community, making it an impossible project. Yet, to assume the perpetual deferral of the coming community does not allow for the ontological and ethical striving that participates, not in a fixed idea of community, but in a fluid structure that opens up the possibility for new forms of collective sociability. I would like to argue that the striving for a coming community, and the formation of a future people, is an ethico-aesthetic activity suffused with an affirmative joy that we can associate with Deleuze's treatment of the concept of a life. The insistence on the indefinite article, $a$ life, determines that no life in particular can be denominated, but that the singularity of any life can participate in community. While admitting that utopia is not the best possible word, Deleuze and Guattari stress that utopia as an idea can become useful through an active engagement with contemporary geopolitical problems (Deleuze and Guattari, 1994: 100); for example, the question of refuge.

Within the specific limits of the discipline of architecture, how can we frame a utopia (no-where) for the problems (now-here) of the present? The architectural theorist, Reinhold Martin, has recently speculated on what he calls utopian realism as a means of transforming feelings of helplessness. This vision is directed not at the distant, inaccessible future, but suggests that in the present things can be otherwise (2005: 5). With such a vision of hope in mind, this essay will address ways in which the concepts of a coming community, a future people and a life can be activated as a practical utopian attitude; an attitude that helps to confront the problems of present architectural discourse and production in a globalized world, where socio-political relations have becomeincreasingly fraught. This essay cannot offer a fixed answer to the question of what kind of architecture will solve the problem of a coming community. Instead, what I attempt here is the articulation of different philosophical constructions of community, to suggest ways in which architecture might reframe its material and theoretical projects. 
I. In a similar vein, Agamben insists that the concept of a life constitutes a pressing problem for a coming philosophy, one that can be returned to a practical calling (Agamben, 1999: 238).

2. An alternative term for composition developed by Deleuze and Guattari is assemblage. Different assemblages, for instance, machinic assemblages and collective assemblages of enunciation, combine bodies, actions, passions, and acts, statements and incorporea transformations respectively. See Deleuze and Guattari (1987).

3. In the English translation by Anne Boyman, we find the term beatitude diluted by being replaced with the term, bliss.

\section{The Structure of the Coming Community}

The structure of the coming community allows us to address contemporary problems, which remain with us as part of our legacy, which demand our attention in the present, and which threaten to pass into the future unresolved unless we take up their challenge. To do so, we need to think, using creative, conceptual processes in the ever mobile and elastic present. As Deleuze suggests: "to think means to be embedded in the present-time stratum that serves as a limit: what I can see and what I can say today?" He adds: "thought thinks its own history (the past), but in order to free itself from what it thinks (the present) and be able finally to 'think otherwise' (the future)" (1988: 119). To frame a practical philosophy, Deleuze turns to $17^{\text {th }}$ century Dutch philosopher, Benedict de Spinoza, for whom the theme of a life evolves through the diminution and increase in our power to act in a world. The greater our capacity to act, the stronger our force of existence, and the more open we are to being affected. Of our relations and acts of creation across a common plane of immanence, Deleuze suggests: "it is a long affair of experimentation, requiring a lasting prudence" (125). ${ }^{1}$ The ethico-aesthetic task of inventing a new people, and a new future, is never one that can be satisfied once and for all.

What is required is the understanding that we are never separate from our common world, and that we do not know in advance what we are capable of, nor what good or bad compositions of the socio-political we might enter into. Deleuze argues that there are "laws of composition and decomposition of relations which determine both the coming into existence of modes, and the end of their existence" (1990: 211). Every thing, person, institution, comes into being through a series of relations, and is transformed in response to encounters, new situations and the admixture of further materials and relations. "When a body encounters another body, or an idea another idea, it happens that the two relations combine to form a more powerful whole, and sometimes one decomposes the other, destroying the cohesion of its parts" (1988: 19). From an architectural point of view, it is important to apprehend that these compositions are not only assembled from the socio-political relations between people, their thoughts and actions. ${ }^{2}$ In the midst of these relations, different kinds of architectural materials and surrounds, and different kinds of human and other bodies intermingle. Architecture can augment forms-of-life by recognizing that its material is animate and inanimate, made up not only of steel, concrete and glass, but also of the social relations between people. New compositions arise through explorative experimentation. Existence becomes an ethical test, though not to determine what is right or wrong. Rather, it determines whether life is augmented or diminished, depending on what compositions it enters into (Deleuze, 1988: 40-41). Whether at the scale of the single cell, the human body, the building, or the institution, these formations are made coherent by relations and compositions, or decompositions, in response to different situations.

Beatitude is a perplexing Spinozist concept, or, rather, a state of being, which is of especial importance in Deleuze's late essay, Immanence: A Life ... A life, or that which participates in absolute immanence, is said to achieve complete potential, and complete beatitude (Deleuze, 2001: 27). ${ }^{3}$ An entire chapter of Deleuze's Expressionism in Philosophy: Spinoza is dedicated to this important concept, which frequently confuses secular audiences. Through the concept of beatitude, 
Deleuze and Guattari describe how Spinoza gives infinite movement to thought: "there he attains incredible speeds, with such lightning compressions that one can only speak of music, of tornadoes, of wind and strings" (1994: 48). While this paper aspires to arrive at the conceptual moment of beatitude, a turn in experience that transports us to an image of thought, it will in all likelihood, and perhaps necessarily, fail. ${ }^{4}$ What I will focus on is the ethical striving for, and composition of, the coming community, and a future people, which is driven by a striving toward beatitude, or what is also known as Spinoza's third kind of knowledge. To achieve this I will, alongside Agamben, and Deleuze and Guattari's work, pass briskly through Jean-Luc Nancy's concept of the inoperative community. ${ }^{5}$ Aside from an orientation directed toward a future, Deleuze, Agamben, and Nancy all describe a circulation of singularities in their formulations of a community to come. I propose that architecture is at the same time composed of singularities, and can be seen as that medium in which further singularities co-mingle.

\section{Giorgio Agamben's Whatever Singularities}

Agamben's coming community is presented to us as a series of fragments, more affective than effective in their argumentation. Agamben does not even give a description of the coming community, which we are to conceptually place in conjunction with a coming philosophy and a coming politics. Instead, he intimates that there is no such community, that it is perhaps nowhere, and, as such, utopian. The coming community appears to be without a place; what's more, it appears to be a community that has never been. Resisting identification as this or that thing, the coming community is patched together out of what Agamben names ' whatever singularities', co-mingling and without identifiable attributes (Agamben, 1993: 85). A difficulty arises here with respect to what can be said about architecture if it cannot be ascribed attributes.

The 'whatever singularities' composing Agamben's coming community own no common ground, no set of beliefs or practices that conjoin them; they merely appropriate belonging as such, according to a structure of being-such (1993: 2). Agamben argues that this is the greatest threat the coming community can level against the state-apparatus. If the state has no means to identify the outlines of this community, how can it placate, order and contain it? We might add that this does not necessarily stop the state from denominating identity. For instance, a community of suspect others may be manufactured on the basis of perceived threat, as in the war against terror, or in the treatment of refugees in the Australian context. In contrast, the striving for a coming community requires that the citizen learn to acknowledge the refugee that he or she is. In We Refugees, ${ }^{6}$ Agamben goes so far as to suggest that our political survival depends on the recognition that we are all, in one way or another, refugees: "The refugee is perhaps the only thinkable figure for the people of our time and the only category in which we may see today ... the forms and limits of a coming political community" (2000: 16). We slowly realize that the so-called citizen has, in a global state of exception, or emergency, become as vulnerable as the refugee.

Agamben asks us to look in the direction of the camp and the figure of the refugee (rather than the nation-state and the figure of the citizen) to begin to imagine
4. Through the concept of beatitude Deleuze and Guattari describe how Spinoza gives infinite movement to thought: "there he attains incredible speeds, with such lightening compressions that one can only speak of music, of tornadoes, of wind and strings" (1994: 48).

5. I will not directly address Blanchot's unavowable community, which is made in response to Nancy. Though Blanchot's murmur might still be heard asking whether it is possible to belong to any community at all, especially that community to which we are obliged to avow our allegiance.

6. This essay is translated as "Beyond Human Rights" in Agamben (2000). Its original title, "We Refugees", is inspired by an essay written by Hannah Arendt, also called "We Refugees" (1943). 
a community to come (2000: 16). But how might we begin to imagine a coming community which - as Mark Holland suggests regarding Blanchot's concept of community - may "never constitute a community except in this mode of 'yet to be'"? (1996: 188). The formulation of a coming community as a state for which we might yearn, but which remains always just out of grasp, only appears to deny the very immanent particularities of a here and now. The permanent flux inherent in the concept of a coming community is akin to becoming, that is, a transformative metamorphosis that draws us into the sphere of life, so that new forms-of-life might be created. Architecture can contribute here, not so much in terms of fixed attributes of durability, beauty, or utility, but by opening up a flexible and responsive material field for new forms-of-life to emerge. Encompassing an intimate relationship with the present as it passes, and expanding into the past as into the future, the coming community does not have to be located in an evasive 'yet to be'. Finally, the coming philosophy must take the concept of life, or $a$ life, as its pressing concern (Agamben, 1999: 238).

\section{Jean-Luc Nancy’s Singular Plural Being}

In contrast, Nancy's coming community has always already arrived. Paradoxically, this does not mean that the necessity of heeding its coming is in any way diminished. In his essay The Inoperative Community, Nancy argues against the most ancient myth of the Western world: the conception of a lost community as a lost capacity after which we still yearn (1991: 9). For Agamben, the coming community has never been; for Nancy, community has never been lost, and there is no such person as the one who has nothing in common. Even in the extreme context of the concentration or extermination camp, where we discover the "will to destroy community", we can also discover resistance (35). From time to time, such resistance has become visible in Australian refugee camps; for instance, through acts of arson, hunger strikes, lip sewing, or successful and unsuccessful attempts at escape.

Nancy identifies community as a "resistance to immanence" (1991: 35): "It is precisely the immanence of man to man, or it is man, taken absolutely, considered as immanent being par excellence, that constitutes the stumbling block to a thinking of community" (1991: 3). This move away from immanence seems to pit Nancy against Deleuze. However, the immanence Nancy critiques places the human subject at its centre. On Deleuze's plane of immanence, neither subject nor object is given prominence, but relations between different moments of becoming appear briefly only to fade away again. Nancy's community is about compearing: an event of singularities, or singular beings, appearing together, a co-appearance that exposes us to our very finitude (1991: 28). Equally, it depends on the concept of partage, a sharing out or division of singular being: "at the limit, the exposition of singular beings to one another and the pulse of this exposition: the compearance, the passage, and the divide of sharing" (1991: 38). An incomplete passage of sharing conjoins at the same time as it splits us apart, by turn distinguishing us, and making us indistinguishable. Nancy calls this an "exposing-sharing" (29), that is, the paradoxical construction of the singular plural. Nancy's community, which has never been lost, while at the same time never achieving completion, participates in a coming: "And what remains thus, or what is coming and does not stop coming as what remains, is what we call existence" (Nancy, 1997: 132). As such, the passage of the coming community 
remains inconclusive (35). Importantly, community is not a work to be produced, though it might be imagined through the creative impulses of writing, art or architecture. These creative practices should not be concerned with erecting monuments, but with facilitating action for the time being. For instance, in a striving for community, the monumentalizing impulse of architecture would have to be redirected to more provisional ends. Despite his questioning of immanence, Nancy shares with Deleuze a belief in the emancipatory promise of the creative act, as well as a formulation of community that does not anticipate a moment of completion. In unison with Agamben, Nancy is also insistent that community owns no essential attributes, but, instead, is an ongoing activity. ${ }^{7}$

\section{The Ethico-Aesthetic Practice of Concept Creation}

LikeNancy, Deleuzeand Guattaribelieve that what a future peoplehavein common is resistance: "their resistance to death, to servitude, to the intolerable, to shame and to the present" (1994: 110). Importantly, a resistance to capture, in a movement of absolute deterritorialization (101), provides the potential for a new earth and a new people. Deleuze and Guattari use the concept of utopia as a figure of political promise, as a critical point from which the present milieu can consider itself and its pressing problems. They appropriate Samuel Butler's formulation of Erewhon (utopia) to designate not only no-where, but also now-here: the patch of new earth where we can pitch our tent for the meantime. A provisional architecture, modest in its aspirations and durable only for as long as the immediate circumstances dictate, could provide a space of potential for this kind of realist utopia.

The coming community of a future people circulates around the construction of new concepts and the identification of contemporary problems. Unlike Nancy's inoperative community, it seems to have work to do. Deleuze and Guattari tell us that a concept is acquired by "inhabiting, by pitching one's tent, by contracting a habit" (1994: 105), but concepts can also be repulsive, and some tents become despicable in their distribution and use. Concepts, much like built architectural forms, can create life possibilities but can also restrict forms-of-life. In any event, the creation of concepts calls for a place where philosophy and art, life and concept can converge, a place to which we can proceed according to a practical, ethico-aesthetics and where the coming community can engage in what Deleuze describes as "the problem of the work of art yet to come" (Deleuze, 1990: 248). This work must constantly resist the deadliness of banality, and the insistence of opinion and cliché. We can work through the power of concept creation as an ethico-aesthetic activity, but first we must increase our power so that we are capable of creative activity.

One of the most radical aspects of Deleuze and Guattari's creative philosophy is that concept creation - as well as the construction of affects and percepts of art, the propositions or functions of science, even the framing capacity of architecture - constitutes ethical and properly political activity. Foucault wrote of Deleuze and Guattari's first collaborative work, Anti-Oedipus, that it was a work of ethics, the first book of ethics to be written in France for quite a long time (1983: xiii). The last book Deleuze and Guattari collaborated on was What is Philosophy?. In pursuing the restless question of the title late in their lives, they were not merely reflecting
7. The temporal orientation of Deleuze and Guattari's future people, or a people to come, also sets us upon a passage toward the future, but with less passivity than evinced by Nancy. Parenthetically, Michael Hardt and Antonio Negri argue in their influential book, Empire, that Deleuze and Guattari have not gone far enough here. They suggest that the pair manage to articulate a future people "only superficially and ephemerally, as a chaotic, indeterminate horizon marked by the ungraspable event" (Hardt and Negri, 2000: 28). 
8. Passive, though passionate passage.

9. Community incorporates singularities in corporeal mixtures and through the circulation of incorporeal effects. For Agamben these are whatever singularities, for Nancy they are singular beings, or singular plural beings as distinct from individuals. Finally, for Deleuze, singularities are less to do with singular beings, as they contribute to both physical states of affairs and to incorporeal, immaterial events: "Singularities are turning points and points of inflection: bottlenecks, knots, foyers, and centers; points of fusion, condensation, and boiling points; points of tears and joy, sickness and health, hope and anxiety, 'sensitive points"' (1990: 52). Singularities are not to be confused with the individual, the subject or the object. For instance, Deleuze tells us that very small children, who might be viewed on the one hand as all alike, have singularities, "a smile, a gesture, a funny face”(200I: 30). Singularities are turning points between affections and processes of creation and contribute as much to the constitution of community as they do to the question of a life. Manuel Delanda, commenting on Deleuze, insists upon a scientific account of singularities that takes us back to Henri Poincaré (2002: 14, 15). Singularities, for Delanda, suggest the long-term tendencies of a given system and lead to new ways of viewing the genesis of physical forms. While Delanda's definition might prove reassuring to some, it is worthwhile remembering that even if the genealogy of Deleuze's use of the concept of singularities can be returned to mathematics and geometry, the philosopher is far more interested in what concepts can do once placed in contemporary assemblages.

10. As well as the parallel passage of thought (mind) and extension (body), and the parallel movement of theory and practice. on lives well lived, but laying out a new plan for ethical becoming. In Deleuze and Guattari's shared project, creativity and ethical activity operate simultaneously. Their project requires a double becoming, a zone of exchange between philosophy and non-philosophy that enables the constitution of a people to come, and a new earth (1994: 109). Though, at first, the temporal structure of the coming community might appear to require perpetual deferral, the ontological and ethico-aesthetic striving we experience toward the constitution of community should not be under-estimated. ${ }^{8}$

In response to Deleuze's essay, Immanence: A Life ..., Agamben argues that Deleuze's attempts to account for a life remain thwarted. A life is not something that can be represented, only intimated. A life is impossible to approach directly, for it shies from our face-to-face confrontation. Yet, something happens on the approach to this question that is inextricably interconnected with the problem of a coming community, a future people and a new earth. With respect to the question of a life, Deleuze writes: "the life of the individual gives way to an impersonal and yet singular life that releases a pure event freed from the accidents of internal and external life" (2001: 28). However, we should not forget that the "singularities and the events that constitute a life coexist with the accidents of the life that corresponds to it" (2001: 29). ${ }^{9}$ Our passivity and our passions, the life we lead, make up the necessary length of the passage toward community, and toward the profound stillness of Spinoza's third kind of knowledge, beatitude. For Nancy, this passivity is non-productive; for Deleuze (after Spinoza), we find it is a matter of progressing from passive to active affections by conjoining life and concepts; that is, it is a matter of becoming active and creating concepts that enable us to enact very material tests on the world in which we are immersed.

Deleuze and Guattari suggest that the passage from joyful passive affections to active affections (Spinoza), or from the inadequate (yet adequate enough) ideas and images of the imagination to the adequate ideas of reason, ${ }^{10}$ is more akin to the uncoordinated leaps of a dog than the explanations of a reasonable person. Caught up in haphazard movements, we proceed through an apprenticeship, which advances in a futural direction not only toward an increase in the power of corporeal and intellectual being, but toward the construction of signs of art that help inaugurate the emergence of another world. Thus, we take a passage that will eventually lead us toward Spinoza's beatitude, as a third kind of knowledge, and through a network of passages along which one becomes, in turn, both lost and found. We will always find ourselves amidst sad and joyful passions. Power constitutes a passage, or point of conversion, the capacity to shift from passions to actions at a moment where "we stop striving to think the world and begin to create it" (Hardt, 1993: 59). We - however this 'we' is differentially composed - arrive at a hiatus of sorts, a pause in our striving, only to continue again into the active creation or construction of concepts, an ethico-aesthetic activity that is fundamental to the ongoing creation of community. Finally, the task is never complete; neither is community, as such, identified through determined attributes. By striving to create new kinds of social relations, and new forms-of-life in relation to environmental situations, community perpetually unfolds. 


\section{The Architectural Problem of the Contemporary Refugee Camp}

As an ethical test of our existence, and the ramifications of our modes of being and becoming, we can begin to apply the above to real spatial coordinates. As Deleuzeexplains, this is not a moral test, but rather like the way in which "workmen check the quality of some material" (1990: 317). Ethics, in this context, is opposed to moral judgment, which determines in advance, according to a fixed code or imperative to act, how a situation will be assessed (Deleuze, 1988: 40). Applying the ethical test of existence is a difficult task, for there are no clear assessment criteria; we are grappling with contemporary problems in the midst of things. We are to remain attuned to how we affect others, and are affected in turn, and that we are never separable from our relations in and with a world. Agamben expressly includes the refugee in the midst of this 'we', and Deleuze allows not just for human, but animal and other bodies. In addition, Martin points out that: "we cannot use the pronoun 'we' to denote a self-consistent, geographically, culturally, or economically unified agent" (2006: 15). Any coming community is composed of diverse relations, compositions and decompositions. It is a matter of aspiring toward the best possible composition, given the situation at hand.

From the midst of things, which situates us upon a plane of immanence, the Australian processing and reception centre, that country's local rendition of a refugee camp, presents a contemporary problem. It could be argued that the camp does not constitute a problem in the arena of architectural endeavour. On the contrary, I would insist that it is part of the task of architecture to recognize the extent of the imbrication of the built environment with modes of life. The body, in its compositions, can be thought of in spatial terms; that is, that the body includes the coordinates of the architecture through which it moves. Within architecture it may discover itself captured in a bad composition, one that leads to its disintegration, or its decomposition.

If the desert camp at Woomera, South Australia, was a bad composition, the Immigration Processing and Reception Centre at Baxter, in the same state, is even worse. From the relative appearance of temporariness at Woomera (composed of so many tents and reterritorialized existing military infrastructures), a permanent and rigid, spatial structure has evolved at Baxter. This purpose-built desert camp, five hours drive from Adelaide, is arranged as a series of nine rectilinear compounds with chamfered corners, expressing a spare architecture. Further, each compound is organized around a grassed courtyard, turning upon its own independent universe, operating in isolation even from the desert setting. The detainees are further fragmented, isolated into groups based on gender, ethnicity, or on whether they can be collected in a family group, or whether they are a threat to themselves and others. The community composed here is arranged so as to form non-communicating cells, and attributes are forced upon the inmates as ready-made templates inhibiting active community formation. Relations between peoples and spaces is regulated and coagulated. The fragile compositions formed are apt to decompose.

Similar socio-political, and very real, material compositions, are also to be found in the midst of Australian cities; for example, in the suburban camps of Villawood 
(Sydney) and Maribyrnong (Melbourne). They exemplify Agamben's intimation that the contemporary city is increasingly indistinguishable from the camp. At the end of tramline 57, the Maribyrnong Immigrant Detention Centre (MIDC), currently the only federal detention centre in Victoria, is set in the gradually, but obviously, gentrifying and redeveloping suburb of Maribyrnong. The briefest of histories of the site reveals different successive compositions, which suggest ways in which a coming community is either welcomed or rejected from within the body politic. Initially, the site was home to British and other migrants who used the original Maribyrnong Migrant Hostel as a transitory refuge before establishing a permanent home in Melbourne. In sharp contrast, the detention facilities today occupy a small wedge of land, a much reduced area of the former allotment. The larger part of the original site, now owned by Victoria University, houses a somewhat ramshackle student village into which the historic buildings have been seamlessly transformed. On either side of a high security wall, mandatory detention and student accommodation are set in a curious adjacency, while the land to the west is being developed into a housing estate.

Inside the razor wire fence of the camp, building works continue to cramp the living conditions of the mostly invisible inmates (see Frichot, 2006). An ethical test applied to the potential composition of a coming community fails here on a number of counts. The camp is spatially segregated, which means that singularities are rendered immobile, thwarting the promise of new expressions of subjectivity. The identity of the camp's inmates is over-determined; they are figured as unwanted others, and a possible threat to the broader community. The potential of the coming community, as it pertains to the Australian context, is diminished exactly through this architectural process of exclusion and stigmatization. Thus, the camp reflects directly on the Australian body politic, negatively determining its attributes. However, this reflection is difficult to perceive for much of the body politic, due to successful attempts to render this suburban camp invisible. The architecture is resolutely non-descript, without expression, generally blank where it faces the outside world. The entire complex is set back from major roads and hidden from view.

From its inception as a migrant hostel after World War Two, to its present day composition of student village and detention centre (the latter surrounded by a double layer of fence and under constant electronic surveillance), the architecture of the site reflects the political attitude at our current socio-political juncture (see Frichot, 2006). It is important to remember that architecture never acts alone in such instances; it remains entangled with the actions effectuated by government policy, material infrastructures existing and new, the migrations of peoples, emerging subjectivities and so forth. Relations that circulate amidst a future people and a coming community have the potential to allow for the creation of socio-political compositions that augment life. In contrast, a composition such as the Australian camp generally removes the capacity to create, and particularly to imagine and create new forms of sociability and community. As Martin suggests, the architectural imagination needs to remain open to the promise that this is not the only possible world, and certainly not the best of all possible worlds (2006: 15). How might architecture, as a specific set of activities, create more positive compositions? 
In the situation of the contemporary refugee camp, we discover the maximum of sad encounters, not just on the part of the asylum seeker, but on the part of those who seek to capture, contain and isolate them, even from their fellow inmates. Thus, the question of the composition of the camp, which decomposes the singularities captured within its confines, and impacts upon the ways in which a coming community might be imagined, becomes an ethical question in the Australian socio-political context today. Therefore, the test is how to concatenate joyful passions, passions that may facilitate common notions that orient active affections or joys toward the positive power of creation and even beatitude. The architectural theorist, Martin, has suggested two simple tasks for architecture: one aesthetic and the other territorial. Architects have the capacity to participate in the aesthetic creation of new built environments that participate in new forms of community. Likewise, architecture can participate in the reconsideration of territorial boundaries that presently dispossess those on the inside as well as those on the outside (Martin, 2006: 21). Yet, there can be no hard and fast moral or ethical rules, as these work against the possibility of responding to the particularities of each new encounter as it presents itself. Hardt suggests that Deleuze "posed the common notion and its process of assemblage as part of an ethical project (becoming active, becoming adequate, becoming joyful)"; but, he asks, "how can we recognize this project in properly political terms?" (Hardt, 1993: 108). If only we could learn to create our mixtures, and form our compositions with some confidence, for as Spinoza frequently reminds us, we are more apt to sad passions. Success or not, it is important to recognize that there are no lasting instructions toward the best possible way of composing community, nor of composing an architecture that responds to the promise of a future people. And since there is never just one approach to a happy life, a form-of-life, a people, a community, our compositions depend on a combination of chance and necessity. We will always wind up with something different, something that could not have been imagined beforehand, for we do not know in advance what we are capable of, nor what good or bad compositions of the socio-political we might enter into.

\section{References}

Agamben, G. (1993). The Coming Community (M. Hardt, Trans.). Minneapolis: University of Minnesota Press.

Agamben, G. (1995). “We Refugees”. Symposium (49) 2, 114-120.

Agamben, G. (1999). Potentialities (D. Heller-Roazen, Trans.). Stanford (Cal.): Stanford University Press.

Agamben, G. (2000). Means Without Ends: Notes on Politics (V. Binetti \& C. Casarino, Trans.). Minneapolis: Minnesota University Press.

Arendt, H. (1943). “We Refugees". The Menorah Journal (3).

Blanchot, M. (1988). The Unavowable Community (P. Joris, Trans.). Barrytown (NY): Station Hill Press.

De Cauter, L. (2004). The Capsular Civilization (P. Bouvier, Trans.). Rotterdam: NAi Publishers.

Delanda, M. (2002). Intensive Science and Virtual Philosophy. New York: Continuum.

Deleuze, G. (1988). Foucault (S. Hand, Trans.). Minneapolis: University of Minnesota Press. 
Deleuze, G. (1988). Spinoza Practical Philosophy (R. Hurley, Trans.). San Francisco: City Lights Books.

Deleuze, G. (1990). Expressionism in Philosophy: Spinoza (M. Joughin, Trans.). New York: Zone Books.

Deleuze, G. (2001). Pure Immanence: Essays on a Life (A. Boyman, Trans.). New York: Zone Books.

Deleuze, G. and Guattari, F. (1987). A Thousand Plateaus (B. Massumi, Trans.). Minneapolis: University of Minnesota Press.

Foucault, M. (1983). Preface. In Deleuze, G. and Guattari, F. Anti-Oedipus: Capitalism and Schizophrenia (R. Hurley, M. Seem, and H. R. Lane, Trans.). Minneapolis: University of Minnesota Press.

Frichot, H. (2006). The Biopolitical Wall in the Midst of Our City. In S. Basson, J. Stephens, T. McMinn, (Eds.). SAHANZ: 2006: Contested Terrains (pp.151-158). Perth, Western Australia: University of Curtain.

Hardt, M. (1993). Gilles Deleuze: An Apprenticeship in Philosophy. Minneapolis: University of Minnesota Press.

Hardt, M. and Negri, A. (2000). Empire. Cambridge (Ma.): Harvard University Press.

Holland, Mark, (Ed.). (1996). The Blanchot Reader. Oxford: Blackwell Publishers.

Martin, R. (2005). "Critical of What? Toward a New Utopian Realism". Harvard Design Magazine (22 Spring/Summer), 1-5.

Martin, R. (2006). “Moment of Truth”. Log ( 7 Winter/Spring), 15-20.

Mills, C. (2004). Agamben's Messianic Politics: Biopolitics, Abandonment and Happy Life. Contretemps (5, December), 42-62.

Nancy, J-L. (1991). The Inoperative Community (P. Conner, L. Garbus, M. Holland \& S. Sawhney, Trans.). Minneapolis: University of Minnesota Press.

Nancy, J-L. (1997). The Sense of the World (J. S. Librett, Trans.). Minneapolis: University of Minnesota Press.

Sorkin, M. (Ed.). (2005). Against the Wall, New York: The New Press. 